\title{
The Action of Acriflavine on Brewers' Yeasts
}

\author{
BY J. W. MILLBANK AND J. S. HOUGH \\ Brewing Industry Research Foundation, Nutfield, Surrey
}

(Received 17 October 1960)

\begin{abstract}
SUMMARY
The absorption of acriflavine by strains of Saccharomyces carlsbergensis and $S$. cerevisiae occurred at approximately the same rate and extent and was greatest in the range $\mathrm{pH} \mathrm{4}_{4-5}$. In this range, the proportion of respiration-deficient cells produced by acriflavine treatment was also maximal. Furthermore, under more alkaline conditions, the acriflavine exerted a pronounced toxic effect. At pH 4-5, the proportion of mutant cells produced was about 50 times greater in strains of $S$. cerevisiae than in those of $\boldsymbol{S}$. carlsbergensis, while fewer cells were killed. With $S$. cerevisiae the production of mutants was rapid and in certain strains exposure for $1 \mathrm{hr}$. to $50 \mu \mathrm{g}$. acriflavine $/ \mathrm{ml}$. led to about one-third of the cells mutating, while after $4 \mathrm{hr}$., all the cells were respiration-deficient. In contrast, exposure of strains of $S$. carlsbergensis for $24 \mathrm{hr}$. at this concentration of acriflavine induced only about one-tenth of the cells to mutate. The mutants took up no measurable amount of oxygen when examined in Warburg respirometers. As compared with the parent cultures, there was no difference in the ability of the cells to utilize carbohydrates and to undergo flocculation.
\end{abstract}

\section{INTRODUCTION}

Ephrussi and co-workers studied respiration-deficient mutants of bakers' yeast which they called 'la mutation petite colonie' (summary, Ephrussi \& Hottinguer, 1951), while Lindegren and his associates refined the techniques for detecting such mutants (Ogur, St John \& Nagai, 1957). Furthermore, the latter, by the use of selective media, demonstrated the effectiveness of a number of agencies in inducing this mutation (Ogur, Lindegren \& Lindegren, 1954; Ogur \& St John, 1956; Nagai \& Nagai, 1958). With this background, the present work was concerned with the mode of action of acriflavine (euflavine), probably the most potent of the relevant agents. From a study of the absorption of acriflavine, its toxicity, and its ability to induce respiration-deficiency in a range of brewing yeasts, quantitative differences in its effect on Saccharomyces cerevisiae and $\boldsymbol{S}$. carlsbergensis were observed. An attempt has been made to define the optimal conditions for such effects.

\section{METHODS}

Organisms. The following yeasts, obtained from the British National Collection of Yeast Cultures (NCYC), were used:

Saccharomyces cerevisiae NCYC, nos. 239, 1062, 1063, 1108 and 1109.

Saccharomyces carlsbergensis NCYC, nos. 396, 397, 398, 399 and 400. 
These strains were selected to cover a range of behaviour, certain aspects of which are important under brewery fermentation conditions, namely ability to form flocs, yeast heads, and chains of cells (Eddy, 1958).

Media. The yeasts were maintained as stock cultures in a liquid malt extract + yeast extract+glucose + peptone medium (MYGP; Wickerham, 1951). Before testing, active cultures were prepared by transferring a small inoculum $(0 \cdot 25 \mathrm{ml}$.) to fresh medium (100 ml.) and incubating at $25^{\circ}$ with gentle shaking for $18 \mathrm{hr}$. Investigations were mostly conducted in a defined medium (A) with a normal $\mathrm{pH}$ of 4.5 described by Kilkenny \& Hinshelwood (1951). Where precise conditions of pH stability were required equal volumes of $\mathrm{m} / 15$ citrate + phosphate buffer and double strength medium A were mixed.

Stock solutions of acriflavine (B.P.C. quality) in distilled water at concentrations of 100 and $1000 \mu \mathrm{g} . / \mathrm{ml}$. were kept in the dark. They were sterilized by steaming on three successive days, and the concentrations adjusted by measurement of optical density at $4400 \mathrm{~A}$., followed by appropriate dilution with sterile distilled water.

Detection of respiration-deficient colonies. After suitable treatment, cell populations were diluted and plated on MYGP agar, and incubated for $48 \mathrm{hr}$. at $25^{\circ}$. The colonies were then overlaid with a solution of triphenyl tetrazolium chloride (TTC) solidified with agar, and buffered to $\mathrm{pH} 7$ (Ogur et al., 1957). Glucose $(0.5 \%, \mathrm{w} / \mathrm{v})$ was added to the overlay mixture for improved resolution of mutant (white) and normal (red) colonies (Nagai, 1959).

Estimation of viability and growth rate in solid media. Suspensions of yeast in media containing gelatin were prepared and examined microscopically over a period of 4-5 hr. at $18^{\circ}$ in a haemocytometer (Gilliland, 1959). Suspensions were prepared in the appropriate medium, with or without acriflavine, containing $6 \%(\mathrm{w} / \mathrm{v})$ gelatin and held at $25^{\circ}$ to preserve the liquid state. While still liquid, one drop of a suspension was transferred to a haemocytometer and the edges of the cover-glass sealed with vaseline. After a period to allow the gelatin to set, the preparation was examined microscopically and the position of each cell noted.

Absorption of acriflavine. Suspensions of yeast cells $\left(10^{8} / \mathrm{ml}\right.$.) were prepared, in $\mathrm{M} / 15$ citrate + phosphate buffer of appropriate $\mathrm{pH}$, together with glucose $(2 \%, \mathrm{w} / \mathrm{v})$ when required. The suspensions were kept agitated with a wrist action shaker. At zero time a solution of acriflavine was added to $50 \mu \mathrm{g}$. $/ \mathrm{ml}$. Samples were removed at once, and at suitable intervals subsequently, and centrifuged. A measured sample of the clear supernatant liquid was diluted appropriately and the optical density (OD) determined, to provide a measure of acriflavine concentration. At $4400 \mathrm{~A}$. there was a linear relationship between $O D$ and acriflavine concentration within the range 0-10 $\mu \mathrm{g} . / \mathrm{ml}$.

Measurement of carbon dioxide evolution and oxygen consumption. These were carried out in a conventional Warburg apparatus, at $\mathbf{2 5}^{\circ}$. Yeasts were grown in MYGP medium for $18 \mathrm{hr}$. at $25^{\circ}$ in gently shaken culture, centrifuged, and resuspended in $\mathrm{M} / 15 \mathrm{KH}_{2} \mathrm{PO}_{4}$ solution ( $\mathrm{pH} \mathrm{4.5)}$. Cell material corresponding to $2 \mathrm{mg}$. dry wt. was used in each vessel. Respiratory substrates $(2 \%, \mathrm{w} / \mathrm{v})$ were prepared in a similar $\mathrm{KH}_{2} \mathrm{PO}_{4}$ solution.

Growth rate of respiration-deficient strains in liquid media. This was followed by turbidimetric estimation of suitably diluted samples. 


\section{RESULTS}

Production of respiration-deficient strains of Saccharomyces cerevisiae and $\mathrm{S}$. carlsbergensis

Strains of the yeasts were exposed to acriflavine at concentrations of 10,50 and $100 \mu \mathrm{g} . / \mathrm{ml}$. in medium A at $\mathrm{pH} 4.6$ for $4 \mathrm{hr}$. A cell concentration of $10^{6} / \mathrm{ml}$. was used. The typical results shown in Table 1 demonstrate that acriflavine had a pronounced mutagenic effect on the strains of Saccharomyces cerevisiae used, but only a small one on $S$. carlsbergensis. These studies were repeated on two strains of

Table 1. Production of mutants of Saccharomyces cerevisiae and S. carlsbergensis by acriflavine

Cultures were treated with different concentrations of acriflavine for $4 \mathrm{hr}$. at $25^{\circ} \mathrm{C}$. After dilution and plating, the resultant colonies were overlaid with a mixture of agar and tetrazolium salt. 'Sectored' colonies are those derived from juxtaposed mutant and normal cells.

Acriflavine ( $\mu$ g./ml.)

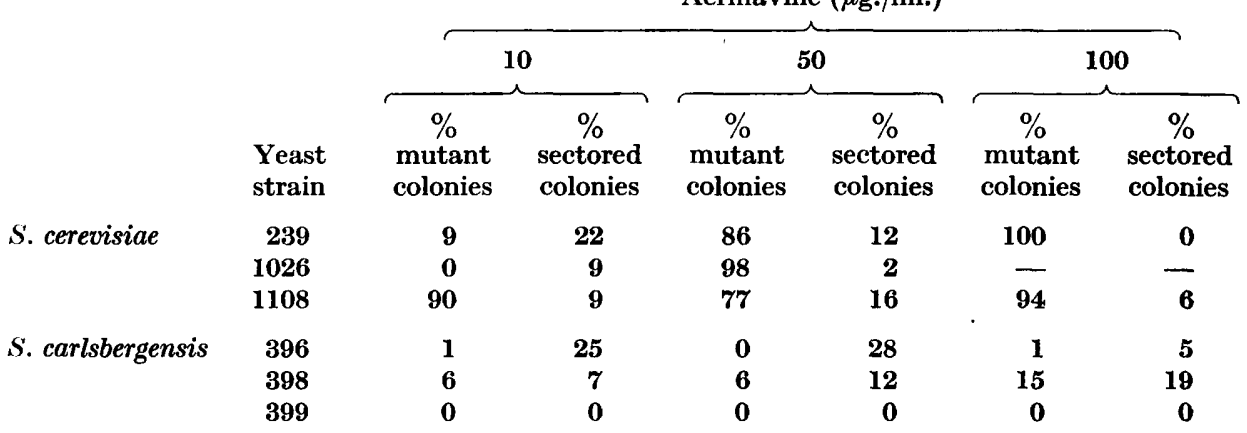

$S$. carlsbergensis with the exposure time lengthened to $24 \mathrm{hr}$, , but respirationdeficient cells still made up only a small proportion of the final population (Table 2). 'Sectored' colonies where they occurred could be accounted for by the tendency of certain strains to form either chains of cells, or flocs, resulting in the juxtaposition of unchanged and mutant cells. This inevitably makes it difficult to draw quantitative conclusions where sectoring was common; therefore, in the majority of trials, the strains $S$. carlsbergensis 396 and $S$. cerevisiae 239 , with reasonably unclustered growth habits, were used.

Table 2. Production of mutants of Saccharomyces carlsbergensis by acriflavine

Experimental procedure was as in Table 1, except that the cells were exposed to acriflavine for $24 \mathrm{hr}$.

\begin{tabular}{|c|c|c|c|c|c|c|}
\hline \multirow[b]{3}{*}{$\begin{array}{l}\text { Yeast } \\
\text { strain }\end{array}$} & \multicolumn{6}{|c|}{ Acriflavine ( $\mu \mathrm{g} . / \mathrm{ml})}$. \\
\hline & \multicolumn{2}{|c|}{10} & \multicolumn{2}{|c|}{$\mathbf{5 0}$} & \multicolumn{2}{|c|}{100} \\
\hline & $\begin{array}{c}\% \\
\text { mutant } \\
\text { colonies }\end{array}$ & $\begin{array}{c}\% \\
\text { sectored } \\
\text { colonies }\end{array}$ & $\begin{array}{c}\% \\
\text { mutant } \\
\text { colonies }\end{array}$ & $\begin{array}{c}\% \\
\text { sectored } \\
\text { colonies }\end{array}$ & $\begin{array}{c}\% \\
\text { mutant } \\
\text { colonies }\end{array}$ & $\begin{array}{c}\% \\
\text { sectored } \\
\text { colonies }\end{array}$ \\
\hline 396 & 9 & 2 & 40 & 6 & 42 & 7 \\
\hline 399 & 0 & 29 & 1 & 96 & - & - \\
\hline
\end{tabular}




\section{Characteristics of respiration-deficient strains}

Cultures obtained by transfer of 'white' colonies after TTC overlay were maintained on slopes of MYGP agar after two transfers in MYGP broth with checking by TTC overlay at each transfer. Their stability was demonstrated by regular testing during periods of up to one year using the TTC overlaying technique and manometric measurements of gas exchange. These tests revealed consistent inability either to reduce TTC or absorb oxygen.

Colony size could not be measured objectively, but diameters of the order of onefifth that of the parent strains were regularly observed after a $48 \mathrm{hr}$. incubation period.

Spectroscopic examination of respiration-deficient strains, grown in MYGP under aerobic conditions at $\mathbf{2 5}^{\circ}$, revealed the existence of a strong absorption band at $5500 \mathrm{~A}$., corresponding to reduced cytochrome $c$; bands at 6000 and $5620 \mathrm{~A}$. corresponding to the $a$ and $b$ components were not visible. All the bands were evident when the parent strain was examined.

It was therefore concluded that the cytochrome complement of the respirationdeficient cultures is similar to that of the 'petite colonie' strains described by Slonimski (see Ephrussi, 1953).

Further evidence of the similarity to the 'petite' strains was provided by the inability of the respiration-deficient strains to grow in media with acetate or lactate as carbon sources.

\section{Demonstration of the direct mutagenic action of acriflavine}

The presence of a high proportion of respiration-deficient cytoplasmic mutants in a cell population that had been exposed to acriflavine might be due to : $(a)$ accelerated growth of pre-existing mutants; (b) direct mutagenic action; $(c)$ accelerated growth of induced mutants. Nagai \& Nagai (1958) suggested that the first alternative is unlikely and the following investigation shows that only the second alternative is applicable.

Saccharomyces cerevisiae 239 and $S$. carlsbergensis 396 and respiration-deficient mutants derived from them, $239 \mathrm{~A}$ and $396 \mathrm{~A}$, were examined by means of the slideculture technique after it had been established that substantially all the cells were viable. The relative number of dead cells was taken as the proportion of cells staining after suspension in $0.01 \%(\mathrm{w} / \mathrm{v})$ methylene blue, buffered at $\mathrm{pH} \mathrm{5.0.} \mathrm{The}$ increase in numbers of normal and mutant cells with and without acriflavine present was followed for a period equivalent to that used in the preparation of mutants (Table 3). Clearly, in the presence of acriflavine the respiration-deficient cells were inferior in their rate of cell division to the corresponding normal cells and, far from being selected, are placed at a severe disadvantage. Their presence must therefore have been a direct effect of the acriflavine. Further, it will be recalled that Table 1 shows, for example, $86 \%$ of respiration-deficient cells in the entire population of S. cerevisiae 239 after treatment with acriflavine $(50 \mu \mathrm{g} . / \mathrm{ml}$.) for $4 \mathrm{hr}$. Table 3 shows that in this period cell numbers have increased by $76 \%$. Hence an original population of 100 cells has increased to 176 cells and $86 \%$ of these (151 cells) are respiration-deficient. It follows, therefore, that at least 51 of the original population had mutated. 
Table 3. Growth of yeasts whilst exposed to acriflavine

Haemocytometer slides were set up containing yeast suspensions in gelatin-solidified medium A, together with appropriate amounts of acriflavine. The cultures were incubated at $18^{\circ}$ for $4 \mathrm{hr}$., and examined microscopically at the beginning and end of this period. Buds having a diameter less than one-fifth of the parent cell were not counted.

\begin{tabular}{|c|c|c|c|c|c|}
\hline & \multicolumn{4}{|c|}{ Acriflavine ( $\mu \mathrm{g} . / \mathrm{ml})}$. \\
\hline & & 0 & 10 & 50 & \\
\hline \multicolumn{2}{|l|}{ Yeast strain } & \multicolumn{4}{|c|}{ Increase in cell number as \% original no. } \\
\hline \multirow[t]{2}{*}{ Saccharomyces cerevisiae } & 239 & 140 & 96 & 76 & 68 \\
\hline & $239 A$ & 100 & 68 & 20 & $\mathbf{5}$ \\
\hline \multirow[t]{2}{*}{ S. carlsbergensis } & 396 & 128 & 66 & 23 & 11 \\
\hline & $396 \mathrm{~A}$ & 28 & 12 & 0 & 0 \\
\hline
\end{tabular}

The optimal conditions for the production of respiration-deficient cytoplasmic mutants

Effect of $\mathrm{pH}$ on mutagenic action. Saccharomyces cerevisiae 239, and $\boldsymbol{S}$. carlsbergensis 396 were incubated in medium $A$ at a range of concentrations of acriflavine, and at $\mathrm{pH}$ values between 4 and 8 . The incidence of respiration-deficient colonies in the suspension was estimated by the overlay technique (Tables 4 and 5 ). Clearly mutation was most pronouced at low $\mathrm{pH}$ values, but the effect of increasing alkalinity was not only to decrease mutagenic action but also to increase toxicity (Albert, 1951).

Table 4. The effect of $\mathrm{pH}$ on the mutagenic action of acriflavine on Saccharomyces cerevisiae 239

Tubes were set up containing yeast suspension in medium A buffered appropriately and acriflavine at 50 or $100 \mu \mathrm{g}$. $/ \mathrm{ml}$.; incubation for $4 \mathrm{hr}$. at $25^{\circ}$. After incubation, the suspensions were diluted and plated on MYGP agar, incubated at $25^{\circ}$ for $48 \mathrm{hr}$. and overlaid with TTC agar. The results given are the means of six replicates.

\begin{tabular}{|c|c|c|c|c|c|c|}
\hline \multirow[b]{3}{*}{$\begin{array}{c}\text { Acriflavine } \\
(\mu \mathrm{g} \cdot / \mathrm{ml} .)\end{array}$} & \multicolumn{6}{|c|}{$\mathrm{pH}$ value of medium } \\
\hline & \multicolumn{2}{|c|}{4} & \multicolumn{2}{|c|}{6} & \multicolumn{2}{|c|}{8} \\
\hline & $\begin{array}{l}\text { Colonies } \\
\text { per plate }\end{array}$ & $\begin{array}{c}\% \\
\text { mutants }\end{array}$ & $\begin{array}{l}\text { Colonies } \\
\text { per plate }\end{array}$ & $\begin{array}{c}\% \\
\text { mutants }\end{array}$ & $\begin{array}{l}\text { Colonies } \\
\text { per plate }\end{array}$ & $\begin{array}{c}\% \\
\text { mutants }\end{array}$ \\
\hline $\mathbf{0}$ & 465 & $\mathbf{0}$ & 357 & $\mathbf{0}$ & 262 & $\mathbf{0}$ \\
\hline 50 & 353 & 84 & 151 & $32 \cdot 5$ & 96 & 22 \\
\hline 100 & 262 & 97 & 131 & 42 & 68 & 54 \\
\hline
\end{tabular}

The original suspension gave 188 colonies/plate, all normal.

Effect of $\mathrm{pH}$ value on the absorption of acriflavine. A study of absorption of acriflavine over a range from $\mathrm{pH} 3$ to 8 revealed no quantitative or qualitative differences between strains Saccharomyces cerevisiae 239 and $S$. carlsbergensis 396 ; the results for the former strain are shown in Fig. 1. The optimal $\mathrm{pH}$ value for absorption, $\mathrm{pH} \mathrm{5,} \mathrm{was} \mathrm{also} \mathrm{similar} \mathrm{in} \mathrm{the} \mathrm{two} \mathrm{strains.} \mathrm{This} \mathrm{was} \mathrm{close} \mathrm{to} \mathrm{the} \mathrm{optimal} \mathrm{pH}$ value for mutagenic action. On the other hand, a considerable absorption took place at $\mathrm{pH} \mathrm{8,} \mathrm{when} \mathrm{the} \mathrm{acriflavine} \mathrm{was} \mathrm{more} \mathrm{toxic} \mathrm{and} \mathrm{little} \mathrm{mutation} \mathrm{occurred.}$ 
Table 5. The effect of $\mathrm{pH}$ on the mutagenic action of acriflavine on Saccharomyces carlsbergensis 396

For experimental details, see Table 4. Period of incubation, $24 \mathrm{hr}$. $\mathrm{pH}$ of medium

\begin{tabular}{|c|c|c|c|c|c|c|c|c|}
\hline \multirow[b]{2}{*}{$\begin{array}{c}\text { Acriflavine } \\
(\mu \mathrm{g} . / \mathrm{ml} .)\end{array}$} & \multicolumn{2}{|c|}{4} & \multicolumn{2}{|c|}{5} & \multicolumn{2}{|l|}{6} & \multicolumn{2}{|l|}{8} \\
\hline & $\begin{array}{l}\text { Total no. } \\
\text { per plate }\end{array}$ & $\begin{array}{c}\% \\
\text { mutants }\end{array}$ & $\begin{array}{l}\text { Total no. } \\
\text { per plate }\end{array}$ & $\begin{array}{c}\% \\
\text { mutants }\end{array}$ & $\begin{array}{l}\text { Total no. } \\
\text { per plate }\end{array}$ & $\begin{array}{c}\% \\
\text { mutants }\end{array}$ & $\begin{array}{l}\text { Total no. } \\
\text { per plate }\end{array}$ & $\begin{array}{c}\% \\
\text { mutants }\end{array}$ \\
\hline $\mathbf{0}$ & 230 & $\mathbf{0}$ & 190 & $\mathbf{0}$ & 370 & $\mathbf{0}$ & 150 & $\mathbf{0}$ \\
\hline 10 & 90 & 13 & 30 & 15 & No growth & 一 & No growth & 一 \\
\hline 50 & 33 & 9 & $\mathbf{2}$ & $\mathbf{0}$ & No growth & - & No growth & - \\
\hline 100 & 17 & 5 & $\mathbf{3}$ & $\mathbf{3}$ & No growth & - & No growth & - \\
\hline
\end{tabular}

Glucose had no effect on the rate or extent of the absorption. The mutagenic action at $\mathrm{pH}$ value of 3 and less was not examined since little absorption took place.

Viability after exposure to acriflavine. Since Saccharomyces cerevisiae and $S$. carlsbergensis differed in their susceptibility to the mutagenic effect of acriflavine, it seemed possible that they might differ also in sensitivity to the toxic action of the mutagen. Estimates of the toxic effect were obtained by using the slide-culture technique. Yeasts were exposed to acriflavine whilst in medium $A$, and were washed three times in saline solution before microscopic examination. The results (Table 6) show that $S$. cerevisiae was resistant to the toxic effect of acriflavine whilst being susceptible to the mutagenic effect, the reverse applying with $S$. carlsbergensis.

Table 6. Viability of yeast after exposure to acriflavine for $4 \mathrm{hr}$.

Yeast strain

Saccharomyces cerevisiae 239

S. carlsbergensis 396

$\begin{array}{cccc}\begin{array}{c}\text { Acriflavine } \\ (\mu \mathrm{g} . / \mathrm{ml} .)\end{array} & \begin{array}{c}\text { Cells } \\ \text { observed } \\ \text { initially }\end{array} & \begin{array}{c}\text { Non-budding } \\ \text { cells observed } \\ \text { after 5 hr. }\end{array} & \begin{array}{c}\text { Viability } \\ \%\end{array} \\ \mathbf{0} & & & 96 \\ 10 & 82 & 3 & 98 \\ 50 & 106 & 10 & 89 \\ 100 & 89 & 5 & 94 \\ 0 & 80 & 0 & 100 \\ 10 & 85 & 10 & 91 \\ 50 & 110 & 34 & 64 \\ 100 & 94 & 44 & 58\end{array}$

The rate of production of respiration-deficient cells. To follow the pattern of appearance of mutants with time at different initial acriflavine concentrations, Saccharomyces cerevisiae 239 was used since it is particularly susceptible to the mutagenic effects over short periods during which the toxic effects are negligible (Fig. 2). The considerable incidence of mutants after $1 \mathrm{hr}$. at an acriflavine concentration of $50 \mu \mathrm{g} . / \mathrm{ml}$. is of interest because less than $12 \%$ of the cells have cleaved during that period in the presence of acriflavine (Table 7). A second feature is the limited mutagenic effect of acriflavine at $10 \mu \mathrm{g} . / \mathrm{ml}$; ; the cell density used such an initial concentration never led to the whole population mutating.

On increasing the concentration of the yeast suspension at constant acriflavine concentration, the production of mutants was progressively decreased. 


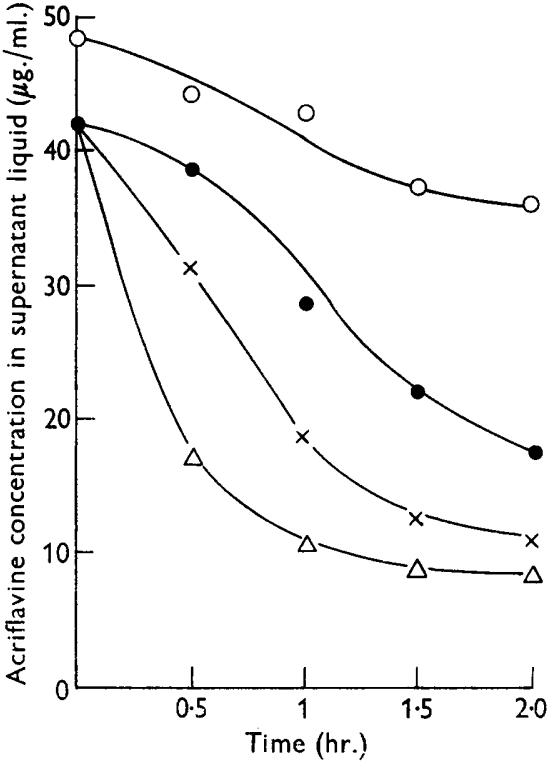

Fig. 1

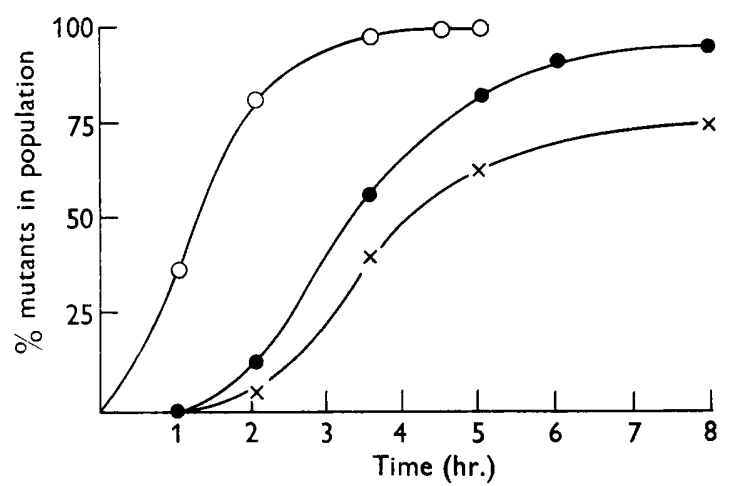

Fig. 2

Fig. 1. The absorption of acriflavine by Saccharomyces cerevisiae 239 . The system comprised : $100 \mathrm{ml}$. yeast $\left(10^{8}\right.$ cells $/ \mathrm{ml}$.) suspended in $\mathrm{M} / 15$ citrate + phosphate buffer. Acriflavine solution was added at zero time, and a sample removed for assay. Suspensions were shaken at $20^{\circ}$. $O=\mathrm{pH} \mathrm{3; \Delta}=\mathrm{pH} 5 \cdot 0 ; \times=\mathrm{pH} \mathrm{7.0;0}=\mathrm{pH} \mathrm{8 \cdot 0.}$

Fig. 2. The production of respiration-deficient mutants with time. The system comprised : Saccharomyces cerevisiae 239, suspended in medium A+acriflavine. Cell conen. $10^{6} / \mathrm{ml}$. Total volume $10 \mathrm{ml}$. Samples $(0.5 \mathrm{ml}$.) withdrawn at times shown. Suspensions shaken gently at $25^{\circ}$. Acriflavine $(\mu \mathrm{g} . / \mathrm{ml}):. \mathrm{O}=50 ; 0=20 ; \times=10$.

\section{Selected physiological characteristics of mutant strains}

Estimates of the endogenous gas exchange were made over $30 \mathrm{~min}$. in the Warburg apparatus. The quotients $Q_{\mathrm{O}_{2}}^{\mathrm{air}}, Q_{\mathrm{CO}_{2}}^{\mathrm{air}}$, and $Q_{\mathrm{CO}_{2}}^{\mathrm{N}_{2}}$ were then measured over the period 10-40 min. after addition of glucose. No measurable endogenous gas exchange was observed with the ten strains tested. The $Q_{\mathrm{Co}_{2}}^{\mathrm{air}}$ and $Q_{\mathrm{CO}_{2}}^{\mathrm{N}_{2}}$ values for any one strain were the same, and for all strains were within the range 150-200 $\mu \mathrm{l}$. $\mathrm{CO}_{2} / \mathrm{mg}$. dry wt./hr. No oxygen uptake was ever observed. However, Slonimski (1958) quoted a diminution of oxygen consumption of $98 \%$, and a residual uptake

\section{Table 7. Growth of yeast in liquid medium + acriflavine}

System comprised Saccharomyces cerevisiae 239 suspended in medium A +acriflavine (50 $\mu \mathrm{g} . / \mathrm{ml}$.). Cell concn. $10^{6} / \mathrm{ml}$. Suspension shaken gently at $25^{\circ}$. At intervals, samples were removed aseptically, diluted, and plated on MYGP agar. Colonies scored after incubation for $48 \mathrm{hr}$. at $25^{\circ}$. Figures are means of six replicates.

$\begin{array}{cc}\text { Time } & \text { Colonies } \\ 0 & 102 \\ 1 & 114 \\ 2 & 125 \\ 4 & 180\end{array}$


of $2 \%$ (about $4 \mu \mathrm{l}$./vessel/hr.) would not be measured with certainty in a conventional Warburg respirometer.

Fermentation characteristics. Four mutant strains were grown on brewers' wort (containing principally fructose, sucrose, glucose, maltose, maltotriose and maltotetraose), and their ability to utilize these constituents compared with that of the equivalent normal strain. No differences were detected.

Flocculation. Eight strains of respiration-deficient mutants showed no change in this characteristic when compared with the equivalent parent strain.

\section{DISCUSSION}

Ephrussi \& Hottinguer (1950) contended that when a population of yeast cells is exposed to acriflavine, respiration deficiency is only manifested in those daughter cells which are produced during the period of exposure or shortly afterwards. The parent cells appear not to be affected by the mutagen and retain their normal respiratory abilities. However, in the present work there is some evidence for direct mutagenic action on the parent cells. Thus from Fig. 2 it is evident that a high proportion of mutants appeared in a population of Saccharomyces cerevisiae which was exposed to acriflavine at $50 \mu \mathrm{g} . / \mathrm{ml}$. for $1-2 \mathrm{hr}$. under conditions where little cell division had occurred (Table 7) and the viability was over $94 \%$ (Table 6).

Differences between Saccharomyces carlsbergensis and $S$. cerevisiae with regard to the mutagenic and toxic actions of acriflavine are not associated with the rates of adsorption of the dye. Perhaps the organisms differ instead in the rate at which acriflavine penetrates the cytoplasmic membranes. However, since in $S$. carlsbergensis relatively few mutants were produced after long exposure, this explanation is not entirely satisfactory. It would seem much more likely that there is a difference between the two species in the materials responsible for synthesis of, for example, cytochrome components. A further explanation can be suggested, namely that equal numbers of mutants are initially produced by the two species but that many of these newly formed mutants of $\boldsymbol{S}$. carlsbergensis are incapable of division. It is, however, unlikely that direct evidence for this explanation can be obtained.

The authors wish to thank Dr A. H. Cook, F.R.S., for his advice and encouragement during the course of this work, and Professor W. O. James, F.R.S., for making available spectroscopic equipment.

\section{REFERENCES}

Albert, A. (1951). The Acridines. London: Arnold.

Evdy, A. A. (1958). Composite nature of the flocculation process of top and bottom strains of Saccharomyces. J. Inst. Brew. 64, 143.

EPHRUSSI, B. (1953). Nucleo-cytoplasmic Relations in Micro-Organisms; their Bearing on Cell Heredity and Differentiation. Oxford: Clarendon Press.

Ephrussi, B. \& HotTinguer, H. (1950). Direct demonstration of the mutagenic action of euflavine on bakers' yeast. Nature, Lond. 166, 956.

Ephrussi, B. \& Hottinguer, H. (1951). Cytoplasmic constituents of heredity. On an unstable cell state in yeast. Cold Spring Harb. Symp. quant. Biol. 16, 75.

Gilliland, R. B. (1959). Determination of yeast viability. J. Inst. Brew. 65, 424.

KILKenNy, B. C. \& Hinshelwood, C. N. (1951). Utilization of carbon sources by certain yeast strains. Proc. Roy. Soc. B, 138, 375. 
NAGAI, S. (1959). Induction of respiration deficient mutation in yeast by various synthetic dyes. Science, $130,1188$.

NagaI, S. \& Nagar, H. (1958). A new evidence for induction of respiration deficiency in yeast by acriflavine. Experientia, 14, 321.

OGUR, M. \& St John, R. (1956). A differential and diagnostic plating method for population studies of respiration deficiency in yeast. J. Bact. 72, 500.

OGur, M., St John, R. \& NaGaI, S. (1957). Tetrazolium overlay technique for population studies of respiration deficiency in mutant yeasts. Science, 125, 928.

Ogur, M., Lindegren, G. \& Lindegren, C. C. (1954). A simple screening test for genetic studies of respiration deficiency in yeast. J. Bact. 68, 391.

Slonimski, P. (1958). In Recent Studies in Yeast and their Significance in Industry. S.C.I. Monograph, no. 3, p. 9. London: Society of Chemical Industry.

Wickerham, L. J. (1951). Taxonomy of yeasts. Tech. Bull. U.S. Dep. Agric. no. 1029. 